\title{
Faith and reality: The role and contributions of the ecumenical church to the realities and development of South Africa since the advent of democracy in 1994
}

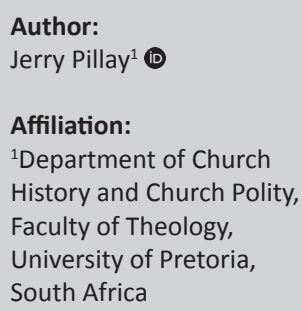

Research Project Registration: Project Leader: J. Pillay Project Number: 04653484

Description:

This research is part of the project, 'African Christianity and Development', directed by Prof. Dr Jerry Pillay, Department of Church History and Church Polity, Faculty of Theology, University of Pretoria, South Africa

Corresponding author: Jerry Pillay, jerry.pillay@up.ac.za

Dates:

Received: 03 Feb. 2017 Accepted: 14 Apr. 2017 Published: 19 June 2017

How to cite this article: Pillay, J., 2017, 'Faith and reality: The role and contributions of the ecumenical church to the realities and development of South Africa since the advent of democracy in 1994', HTS Teologiese Studies/ Theological Studies 73(4), 4519. https://doi.org/ 10.4102/hts.v73i4.4519

\section{Copyright:}

(C) 2017. The Authors. Licensee: AOSIS. This work is licensed under the Creative Commons Attribution License.

Read online:
Many Christians feel quite disillusioned and disappointed with the church in South Africa today because they assume that the church, in particular the South African Council of Churches (SACC), is not playing an adequate prophetic role in building the democratic South Africa since 1994. This article traces the role and contributions of the SACC and other ecumenical organisations to the building of a democratic South Africa. It establishes that whilst the SACC had lost its focus and vision and has an ecumenical body, largely because of its partnership with government, it does, nevertheless, continue to contribute to the building of the South African nation.

\section{Introduction}

Much has been written about the role and contributions of the church in the struggle against, and the dismantling of, apartheid in South Africa (e.g. De Gruchy \& De Gruchy 2004; Hofmeyer, Millard \& Froneman 1991; Plaatjies-Van Huffel \& Vosloo 2013). However, very little has been written from a church historical point of view about the role of the church in the development and shaping of democracy in South Africa since 1994. This article attempts to provide a historical survey of the role and contributions of the church, specifically, in building the new democratic South Africa. It pays particular attention to the struggles of the South African council of churches (SACC), the split in the ecumenical movement and the efforts of the church to impact on the realities in South Africa since 1994 until the present. In spite of all the challenges, the church has contributed to the building of the democratic South African nation. I shall illustrate this by examining archival material and information extracted from mainly the primary sources such as statements, pronouncements, press releases, events, minutes and actions undertaken by the church within the period mentioned.

\section{South African Council of churches: Liberation and democracy}

Most churches in South Africa have understood the need to connect faith with everyday life experiences. Given the political reality of the apartheid South Africa churches, essentially the main line churches, had no option but to get involved in addressing issues of oppression and racism (see, for example, Plaatjies Van-Huffel \& Vosloo 2013). The SACC, consisting of 26 member churches, in particular, played a very vital role in the dismantling of apartheid. It became the spiritual home for the oppressed and poor as it gave hope and support to families with members killed and in prison or exile. The ecumenical movement in South Africa identified itself with the poor as it joined forces with the exploited working class. Embracing liberation theology, it insisted that God is on the side of the poor, and it therefore joined with the poor to fight for justice and human rights. In seeking the liberation of the oppressed, it radically opposed the structures that dehumanised the masses. It encouraged the participation of the poor in the processes of enabling them to become more human. It raised consciousness of the oppressed in South Africa both internally and internationally. The SACC, together with labour movements and civil society, actively resisted the apartheid laws that were imposed on the majority of people in South Africa by calling for disinvestments and international sanctions on South Africa.

Prior to 1994, the SACC was an incredibly strong organisation which boasted clarity of vision and theological grounding in its work. It had a strong sense of purpose and direction embedded in an

Note: This paper was presented at the Third Joint Conference of Academic Societies in the field of Religion and Theology, 11-15 July 2016 at the University of Pretoria, South Africa. 
authentic prophetic voice of the oppressed and voiceless. It provided a space for worship and home for the oppressed. It was seen as an instrument and beacon of hope. It enjoyed the support of the grassroots and many ordinary people wanted to be involved in the work of the SACC in different ways. It had a high international profile and was extremely well supported by foreign donors. It had a unifying force for the communities and the churches (SACC ${ }^{1}$ 2009a).

After the advent of democracy in South Africa in 1994, the SACC seemed to lack a clear vision and corporate identity. Its strong and clear theological rationale and ecumenical vision dwindled. It lacked a pastoral plan to deal with new and emerging moral, social, political and economic challenges. Overall, it lacked a uniting theological force among members. There emerged different visions and missions among Provincial Councils and a disconnection with the aspirations of the poor and grassroots communities. ${ }^{2}$ It suffered a weakened prophetic voice because of its fear and reluctance to speak out on governance and moral issues such as abortion, same sex marriages and the situation in Zimbabwe. Needless to say, it also lost great support from donors and it was forced to retrench staff and close programmes because of the lack of funds (SACC 2009a).

One would have imagined that after 1994, the SACC would have continued to play a role in the reconstruction and development of South Africa, especially in building and sustaining the democracy of the country. However, after 1994, the SACC is described as a weaker organisation (SACC 2009a). There are several reasons for this as we have already indicated. Adding to these, De Gruchy and De Gruchy (2004:207) establish that during the struggle years, ecumenical church leaders had assumed a political role by default because of the banning of the liberation movement. However, when liberation came some church leaders seemed to withdraw from political involvement and attended to the institutional needs of the church. De Gruchy points out that this is partly true but it is also a misperception because many church leaders and pastors who had been actively engaged in the struggle continued to be involved, recognising that whilst their precise role had changed, there was still an urgent need for their contribution in the on-going process of democratic transition and social transformation.

Some of the notable SACC leaders such as Frank Chikane, Allan Boesak, Brigalia Bam and Molefe Tsele joined the government in different capacities and, undoubtedly, contributed significantly to the development of the emerging new South Africa. Unfortunately, with their movement to government there was no real development of future leaders in the SACC and, worse still, the independence of the church was compromised. The SACC took the position of 'critical solidarity' in its relationship with the state and encouraged its members to work with

1.This was an evaluation conducted by CORAT AFRICA at the request of the SACC in 2009. It did extensive research, interviewing church leaders, congregants, donors and others on the work of the SACC.

2.It must be noted that the regional and provincial structures of the SACC were quite instrumental in working for change, development and reconstruction on the ground. It was here that the 'ecumenical voice' and work continued to persist for a long time, but this is also now under pressure with the closing of many provincial long time, but this is also now under pressure with the closing of many provincial
offices. This study is focused on the SACC as a national body and will, therefore, not undertake to examine the contributions of the regions and provincial councils. government agencies in the delivery of services or in pursuance of common national objectives. This was, of course, significant in the attempt to build a new South Africa. Unfortunately, this approach also leads to the weakening of the SACC and the cooption of some of its leaders possibly without them being aware of the impending dangers that awaited the ecumenical church. Whilst some of the leaders, as mentioned above, still kept their feet in the church, they became champions for the support of the government. It turned out that the SACC was more in 'solidarity' with the African National Congress (ANC) ruled government rather than being 'critical'. The prophetic voice was diluted, if not diminished and led to the weakening of the SACC. The SACC later took on the position of 'critical engagement' in its relationship with government but the damage was already done. It is interesting to note that some of these leaders have returned to leadership in the church but their past relationship with the state and their present concerns and public criticism of government does not help the ecumenical church in any further way.

The CORAT Report (2009a) indicated the concerns expressed by member churches. They wondered how the SACC will continue to rely on public resources without compromising its prophetic responsibilities and challenge the government on issues of justice. They feared that government funding of Provincial Councils would stifle the ability of the provinces to fulfil their advocacy role effectively. They asked how can the SACC maintain a critical distance without been seen as an extension of the ANC. Further, they were concerned about how the SACC would regain its prophetic voice and continue to engage with government on the realities and issues in South Africa related to landlessness, economic policies, illegal mining, poverty, HIV and AIDS, unemployment, freedom fighters, corruption and crime among others. They questioned how the SACC will maintain a balance between attending listening to the aspirations of grassroots communities and at the same time to the high profile government-defined agenda. In short, members stated that they need the SACC that is a council of churches and not a satellite body of the government. It was the latter connection that was going to cost the SACC dearly in its on-going standing and recognition within the South African nation.

\section{Ecumenical movements and activities}

The position of the SACC in the South African context was further weakened by the emergence of other bodies, even from within the SACC. For example, the formation of the National Initiative for Reformation in South Africa (NIRSA) and the Southern African Christian Leadership Assembly (SACLA) gathered Christians from virtually all denominations to respond to the realities in South Africa. This was an initiative of African Enterprise (AE) and The Evangelical Alliance of South Africa (TEASA). Perhaps their attempt at taking such a lead was an expression of their frustration of the SACC's collaboration and identity with government. They were calling for people of faith to work for transformation and change in South Africa. 
It is thus not surprising that the SACC General Secretary, Mr Eddie Makue, was critical of this initiative in his report to the Central Committee, in May 2008. He stated:

We are concerned that the occasional SACLA meetings develop resolutions and raise expectations unduly. While the SACC do not claim sole propriety of ecumenism it is vital that we guard against initiatives undertaken, under the banner of ecumenism that fails to effectively follow on the resolutions taken. Such experiences does not auger well in our efforts for ecumenical cooperation. (p. 28)

Another initiative which distracted the work of the SACC was the formation of the National Religious Leaders Forum (NRLF). This network emerged from former President Nelson Mandela's request for all religious bodies to establish a forum so that government could speak to all of them together. The NRLF had an audience with President Mandela where faith-based organisations were able to dialogue with government on pressing issues and participate in building a democratic South Africa. These dialogues continued quite intentionally with former President Thabo Mbeki when he succeeded President Mandela. Unfortunately, these meetings with President Mbeki turned out to be more of the government seeking approval and support for its policies rather than hard engagement on issues in South Africa, even issues threatening democracy. Some of these issues identified by the SACC (2008) were: the political and economic crisis in Zimbabwe, the plight of the poor, crisis of governance in some state institutions, the break out of violence directed at foreign nationals, unacceptable levels of violent crime, leadership vacuum and lack of accountability, violence against women, increasing competition for finite resources, and environmental degradation and climate change.

There came a time when the NRLF was able to express its concern about the setting of the agenda and the participation of religious leaders in the meeting with the president. President Mbeki heeded to the call and voice of the religious leaders and agreed on the setting of the agenda together and equal participation in the meetings, which took place at least two times a year. The meetings thus became more acceptable though not fully what was desired. It is in this light that the late Russel Botman (1997) pointed out that the church's engagement with government is usually:

on an issue-to-issue basis and the church is more likely to be reactive rather than proactive. Government acts, Christians react after the fact. Political parties, special interest groups make the rules, set the agenda and dictate the nature of the game. (p. 78)

In response to this, Botman called for a true Christian presence that is comprehensive and sustained in participation in the political community in which the church participates in the full process: setting the agenda, making the rules and critically examining the outcomes.

The SACC welcomed the interfaith cooperation in South Africa but expressed disappointment at first when the Forum 'erroneously started taking on the form of an organisation' (Makue, General Secretary Report 2008). According to the
General Secretary, with the formation of the National Religious Association for Social Development (NRASD), operating as a wing of the NRLF, this concern became profound. Thus, the National Executive Committee (NEC) of SACC - in October 2008 directed the General Secretary to formally raise the SACC concerns with the NRLF chairperson.

In spite of the challenges faced by the SACC and the widening of the ecumenical space and players in South Africa since 1994, the church through these various structures continued to speak into the South African context. Whilst the SACC may have somewhat relaxed its prophetic voice, other voices such as TEASA, AE and the NRLF started to fill that gap. They have called significant consultations to analyse the situation in South Africa and issued prophetic challenges on the South African government. The Evangelical Alliance of Southern Africa (TESA), in particular, has managed to solicit many professional and business people to help support its work voluntarily and financially. The Church Leaders Forum and 'Think Tank' has done and continues to do regular analysis of the political and socio-economic challenges in South Africa The SACC was always respected for its role in campaigning against apartheid, and the other ecumenical movements in South Africa duly acknowledge this with appreciation. However, the biggest threat to the ecumenical unity in South Africa was to emerge with the change of the Mbeki administration in South Africa.

\section{Ecumenical fragmentation}

On 20 September 2008, with about 9 months left in his second term, President Mbeki announced his resignation after being recalled by the NEC of the ANC, following a conclusion by Judge C.R. Nicholson of improper interference in the National Prosecuting Authority, including the prosecution of Jacob Zuma for corruption. Though this was unanimously overturned by the Supreme Court of Appeal on 12 January 2009, the resignation stood. The SACC leadership since 1994, as we pointed out earlier, was generally favourable to the Mbeki administration in South Africa and thus questioned the Polokwane events that led to Mbeki's departure as President of the Republic of South Africa. The SACC went even further by publicly opposing the appointment of Jacob Zuma as Mbeki's successor on the grounds of morality and corruption which it felt did not qualify him for such a high office in the land.

Jacob Zuma became the next President of South Africa and it became fairly apparent that the SACC was soon to be sidelined from the Presidency. The words of the SACC, in a public statement issued on 10th March 2010 titled Telling the truth from a position of weakness, for in our weakness, we are perfected by our Lord, clearly indicates this perception: 'We have also observed unwillingness from the Presidency to engage with the SACC'. The statement made an even greater claim expressed in the following words:

Central Committee is appalled by the fragmentation of the ecumenical organisations in this country. This situation is made worse by some of the interventions of the ruling party and its 
Commission for Religious Affairs which appears to have taken it upon itself to reconfigure the ecumenical space. They have since formed a new entity called the National Interfaith Leadership Council (NILC) which in our view replicates the work of the NRLF. It also creates- perhaps deliberately- a lot of confusion among our members. (SACC Statement 2010:1)

The same statement called for all Christian ecumenical bodies to unite in witness, it agreed to engage with NILC but stated that it would maintain distance from that body and not become a member. It is interesting to note how NILC came to the government's defence on the issue of e-tolls and in 2015 when the SACC refused to accept the apology of President Zuma for bringing the South African economy into jeopardy by firing the then Minister of Finance, NILC publicly took a different stance in support of Zuma.

The lesson the SACC learnt from its relationship with government is that it goes well when it gives support for government but not so well when it decides to be critical of the Presidency. It has learnt that it must remain at a distance in its relationship with government so that it may keep clear the way for prophetic engagement. The SACC has discovered that government also finds a way to fragment the ecumenical voice and muster support for itself. The SACC has come to the realisation that it must never lose its focus on the poor and marginalised. We shall now briefly trace the development of the ecumenical movement in South Africa since 2011, again with special reference to the SACC.

\section{New ecumenical risings}

Drawing from the 2009 CORAT Report, the SACC undertook another strategic planning meeting on 01-02 February 2011. It reviewed the mission statement as stated in the Triennial Conference, namely:

The SACC works for moral reconstruction in South Africa, focussing on issues of justice, reconciliation, integrity of creation and the eradication of poverty and contributing towards the empowerment of all who are spiritually, socially and economically marginalised. (CORAT Report 2009:15)

It is clear from this that the SACC is attempting to reposition itself and aiming to address the key issues in building a free and democratic South Africa. It aims to do this by focussing on issues of justice, working on reconciliation and healing of the nation, eradicating poverty and taking up the challenges of the marginalised.

This was further reflected in the Triennial Conference of the SACC from 25 to 26 February 2014 under the theme 'God of Life: Renew, Restore and Transform us for the service of Your Kingdom'. The conference gave thanks to God for changes in South Africa since the birth of democracy in 1994 but expressed concern for the lack of significant progress in the areas of education, health and social transformation. It called for the safety of children, addressing of inequalities and a focus on the needs of the poor in the efforts to continue to build the democratic South Africa (Statement issued on 28 February 2014, accessed kairossouthernafrica.wordpress.com).
Though the SACC is refocused with its new vision and mission, the lack of financial support and involvement of member churches make it difficult to implement its strategic plan. It is difficult to regroup, muster support and communicate the vision of the SACC. However, the SACC has succeeded in reclaiming its prophetic voice and role in reconstructing a broken South Africa. In March 2015, representatives from the SACC met with key leaders from the ANC to outline their concerns about the situation in South Africa. They stated clearly that the:

history of relationship between the SACC and the ANC is a fact of common struggle for universal human rights in South Africa based on a democratic dispensation with justice for all without regards to any distinctive physical attributes and according due dignity to all as created in the image of God. Thus the common struggle was not only on the common 'enemy', i.e. the apartheid regime, but more so it was a common struggle for the creation of a just and transformed society. (see SACC 2015:2)

In stating the above, the SACC indicated to the ANC that whilst it exercised the element of solidarity, it must be allowed the right to be critical of the ANC. It pointed out that whilst it may publicly acknowledge the success of the ANC and the government it leads, at the same time it has to point out what the dropped catches are. 'Gainst the wrong that needs resistance; for the good that lacks assistance' (Ibid.:4, no. 22). Against this background, the SACC outlined some of the challenges facing South Africa today. It pointed out that there is a lack of confidence in the ANC and the government it leads. This is demonstrated in the rise of community protests and disillusionment among many South Africans - black and white, urban and rural. The lack of confidence in the ANC government is generated, among other things, by the growing culture of corruption and maladministration, parastatal instability; for example, South African Broadcasting Company (SABC), Eskom, National Prosecuting Authority (NPA), South African Airways (SAA), South African Police Services (SAPS/HAWKS) and the Independent Electoral Commission (IEC), pursuit of inexplicably expensive and uncanvassed options for the country such as nuclear power for electricity, e-toll system in Gauteng, the digital migration saga, the Marikana tragedy, and the Nkandla issue. Added to these are the concerns of increasing poverty, inequality, unemployment especially among youth, drop-out rates in schools, violent rape and domestic violence, marriage dissolution and social strife. The SACC committed to address the critical matters placing poverty at the top of the list and expressed the hope for dialogue and partnership in the joint struggle.

Acting on its promises in this meeting with the ANC, on 11 June 2016 the SACC launched its campaign called The South Africa We Pray For! A Call to Pray and Work for Sustained Hope in Humility and Faith. It stated that church action would be informed by burning community concerns, credible research and rigorous spiritual and theological reflection. It called on all congregations to 'pursue doing the good that transforms society'. It presented a challenge for South African Christians and all people to be involved in healing and reconciliation, healing past trauma, affirming the family life, poverty and 
inequality, transforming unequal economic power relations and in anchoring democracy.

South African Christian Leaders Initiative (SACLI) was formed in 2011. This was a significant effort in attempting to unite the Christian voice in South Africa. It brought together four ecumenical organisations in South Africa, namely: TEASA, SACC, AE and Kairos. In a 2011 media statement, it was said that:

A historic meeting of Church leaders took place Tuesday, 15th November, at Bishopscourt in Cape Town. Its aim was to tackle divisions between historic and newer churches, where labels such as 'ecumenical' and 'evangelical' have undermined a broader shared Christian witness within society and nation. Leaders made a renewed commitment to enhance working together for the good of all South Africans. (Statement issued by the SACC-TEASA-AE at Bishopscourt 2011)

This initiative was taken further in October 2012 when a group of 18 leaders met in Stellenbosch to begin to focus on the role of the church in South Africa and ask: Where is the church's voice? There was a great sense of frustration that the church was not engaging with the realities of the time and remaining silent about the corruption and violence that was taking place in the country at that time. Out of that meeting, three initiatives were launched: a 23 Day prayer initiative, the Statement 'The church speaks, for such a time as this', and the agreement to hold the South African Christian Leadership Indaba.

The Statement 'The church speaks ... for such a time as this' (ddp.org.za) was issued on 25 November 2012. It aimed at addressing the ANC as it approached its conference in Mangaung in December 2012, but also addressed those within the broader political and economic spectrum and especially those within the churches and the poor and oppressed in South Africa. It expressed confession of the church for not fully implementing the Rustenburg declaration of 1990 and not standing united against poverty. It reflected on the question: 'Is there hope for our democracy?' It called on political leaders to recognise the loss of hope and the growth of cynicism and anger, of which Marikana and De Doorns are massive signals, repent of corruption and selfservice, display integrity in politics, listen to the voice and needs of young people in the country, stop the compromising and decay of the education system and to implement the National Development Plan. It called for a new kind of politics that will bring abundant life to all with a healthy democracy in South Africa. In a similar way, it challenged economic leaders and trade unions to address poverty, economic inequalities and unemployment. The Statement concluded by addressing the poor and asserting the commitment to developing the democracy in South Africa. The Indaba was held in Kempton Park from 22 to 24 January 2013. It drew together over a 100 people from most of the denominations in South Africa. The Indaba expressed a sense of urgency for the church to respond to the crisis in South Africa. It reflected on the leadership crisis, lack of unity and issue of church and state relationships. It puts together a mission statement which reads thus, 'SACLI stands ready to serve the church in transforming our world together for His Glory'. Further, SACLI sets its strategic goals to build greater unity in and among churches, exercise a prophetic witness in society, develop and implement a long-term plan and process for the church to journey together for social change and establish a dynamic people movement in South Africa. SACLI embarked on a Democracy Development Plan and worked on a 30-year master plan for South Africa.

Whilst this research focuses on the role of ecumenical bodies in addressing the realities in South Africa, it is important to point out that the new ecumenical space is not just with ecumenical organisations and church leaders but with ordinary Christians who are daily seeking to understand their faith in a world of conflict, struggle and suffering. SACLI was quick to recognise this. In a historic meeting in 2013, it called together Christians from all areas of business, labour, government and society to mobilise them for transforming society wherever they are found with the impact of the Christian gospel. It is interesting to note that it identified true ecumenism to be found in ordinary Christians and not just in church leaders. Conradie (2013:67) points out that in South Africa there seems to be a tension between grassroots ecumenical fellowship and national ecumenical structures. He establishes that ecumenism is alive and well in local communities throughout South Africa. Whilst maintaining their distinct denominational identities, lay Christians seem to have no problem in joining hands in prayer groups, marches, funerals, Bible study groups, community structures, governing bodies, soup kitchens, trade union meetings, etc. In many places, local ecumenical initiatives have contributed to a renewal of local congregational life and the unity of the church becomes a concrete reality. New impulses are also given to regional, national and international ecumenism by such local efforts. Here, the focus is not on ecclesiology but on mission (Pillay 2015:638). The truth is that national ecumenical movements are being overtaken by reality and they cannot find the drive to keep in flow with the spirit. This calls for radically re-thinking on how we do ecumenism today in South Africa (Pillay 2015:650).

The National Church Leaders' Consultation (NCLC) gathering at OR Tambo International Airport from 22 to 23 October 2014 reflected on being the church in South Africa and the national challenges South Africans face as we celebrate 20 years of democracy. It expressed its commitment to a united ecumenical witness and action and appreciated the interreligious dialogue and cooperation in South Africa. It also confessed to the brokenness and pain in society admitting that 'we are not conduits of creating a just and peaceful society'. Whilst acknowledging South Africa's constitutional democracy, positive changes giving citizens access to basic services, and the restoring of international standing, it pointed out challenges in a number of areas such as: poverty and unemployment, crime, corruption and fraud and violence against women and children (NCLC 2014). 
Reflecting on the political culture after 20 years of democracy, the Statement cautioned against romanticising democracy against the very real backdrop of the vast majority of black South Africans still experiencing the pain, suffering and exclusion of being trapped in poverty and inequality. It also called for the upholding of the constitution as the embodiment of the democracy. In this regard, the meeting strongly emphasised the need to defend the Public Protector and her office against the political onslaught they were experiencing in the wake of, among others, the 'Nkandla-gate' scandal. The meeting also called for the active involvement of faith networks, civil society and business in the implementation of the National Development Plan. It further expressed serious concern about education, Early Childhood Development, social and welfare policy, energy and ecology, food security and land redistribution, health care, HIV and AIDS, sexual and gender-based violence. The meeting considered that all of these mentioned issues have to be addressed if we are to build a truly democratic South Africa.

In 2015, huge unrest broke out at South African universities prompted by the \#FeesMustFall campaign initiated by students in protest of escalating student fees. They demanded free education as promised by the ruling party leading the government in South Africa. Church leaders joined with students in their protest stating:

we lament the exclusion of the poor from our spaces of higher education because of unaffordability. We recognise that the majority of these students are black and this entrenches inequality in our nation and denies educational opportunity. Our sacred texts call us to identify with the poor and marginalised. The church and faith leaders therefore have an obligation to stand in solidarity with students on campuses around the nation. (NCLC Statement on the student fee crisis, issued on 22 October 2015)

Not only economic disparities and equalities but also the resurgence of racism and the interferences in the freedom of the press in South Africa in recent times stand as a huge threat to South Africa's democracy. The ecumenical movements in South Africa continue to address these challenges but their 'voice' is not widely and adequately heard. The media, for example, does not give churches adequate public coverage. Hence, many Christians in South Africa increasingly feel that the church is silent on very significant public issues, simply because they do not know or have not heard the church speak. They continue to yearn for the prophetic voice of the church. The church needs to reclaim its role in working for justice, peace, reconciliation $^{3}$ and healing as it continues to contribute to the building of the democratic South Africa. Whilst it would have to partner with others, including government, to achieve this end; it must at all times retain and preserve its distinctive and prophetic voice. The failure to do so may lead to its own demise, which we currently see in the struggles of the SACC (Pillay 2015:637).

3.For more on reconciliation see Maluleke (2005:105-120)

\section{Conclusion}

In this research, I have attempted to trace the involvement of the church in building a democratic South Africa. I have showed that the ecumenical movement, the SACC in particular, played a vital role in dismantling apartheid. It was expected to play an equally important role in building the new South Africa. However, along the way it lost its focus on the poor and sided with the new government in the process losing its prophetic voice. This prophetic voice was taken over by other ecumenical movements within South Africa. Today, the SACC has managed to re-establish its ecumenical vision and prophetic witness alongside, and with other ecumenical bodies, but it still struggles to survive. The church is in a renewed kairos of prophetic witness and democracy-building in South Africa (Goranzon 2011). Perhaps this kairos also warrants the reconfiguration of the ecumenical movement or the start of something new to give it greater acceptance and impact, not driven by historic nostalgia ${ }^{4}$ but by the earnest desire to continue to allow faith to speak to the realities of our time.

\section{Acknowledgements Competing interests}

The author declares that he has no financial or personal relationships which may have inappropriately influenced him in writing this article.

\section{References}

Botman, R., 1997, 'Towards a world-formative Christianity in South Africa', in G. Mongezi \& L. Milton (eds.), An African challenge to the church in the 21st century, Salty Print, Cape Town.

Ceruti, D., 2011, Strategic planning meeting report, Johannesburg.

Conradie, E.M., 2013, South African perspectives on notions and forms of ecumenicity, Sun Press, Stellenbosch.

De Gruchy, J. \& De Gruchy, S., 2004, The church struggle in South Africa 25th anniversary edition, SCM Press, London.

Goranzon, A., 2011, The prophetic voice of the South African Council of Churches after 1990: Searching for a renewed Kairos, Swedish Institute of Mission Research, Sweden.

Hofmeyer, J.W., Millard, J.A. \& Froneman, C.J.J. (eds.), 1991, University of South Africa, Pretoria.

Makue, E., 2010, SACC Press Statement: "Telling the Truth from a position of weakness, for in our weakness, we are perfected by our Lord, SACC Press Statement, Johannesburg.

Malueke, T., 2005, 'Reconciliation in South Africa: Ten years later', Journal of Theology for Southern Africa 123, 105-120.

Mgojo, K., 1995, 'The Church in history: Struggle and challenge', in B. Pityana \& C. Villa-Vicencio (eds.), Being the church in South Africa, SACC, Johannesburg.

National Church Leaders Consultation (NCLC), 2014, Church Leaders Statement, OR Tambo International Airport, Johannesburg.

National Church Leaders' Consultation (NCLC), 2015, Statement on the student fee crisis, Southern Sun Hotel, OR Tambo International Airport, Johannesburg.

Ntlha, M., 2012, South African Christian leaders initiative statement, Johannesburg.

Pillay, J., 2015, 'Ecumenism in Africa: Theological, contextual and institutional challenges', The Ecumenical Review 67(4), 635-650. https://doi.org/10.1111/ erev.12197

Plaatjies-Van Huffel, M.A. \& Vosloo, R. (eds.), 2013, Reformed churches in South Africa and the struggle for justice: Remembering 1960-1990, Sun Press, Stellenbosch.

4.The SACC believes that it must not lose the heritage of its struggle against apartheid, and rightly so. However, many conservative and evangelical Christians cannot see and rightly so. However themselves becoming part of the SACC because of previously ingrained thoughts and perceptions. For example, the apartheid regime branded the SACC has liberals, communists and terrorists. In light of this, I pose the need of birthing something new as a unified ecumenical movement in South Africa. 
South African Christian Leaders Initiative, 2014, Synopsis of the SACLI - GIBS dialogue, University of Pretoria, Pretoria.

South African Council of Churches (SACC), 2006, Towards abundant life: Accelerating and sharing growth, Johannesburg.

South African Council of Churches (SACC), 2008, Give us this day our daily bread minutes of the central committee, Cedar Park Conference Centre, Johannesburg.
South African Council of Churches (SACC), 2009a, CORAT AFRICA: Evaluation report, Johannesburg.

South African Council of Churches (SACC), 2009b, Minutes of the meeting of the central committee, Johannesburg.

South African Council of Churches (SACC), 2015, A discussion paper with the ANC by the SACC, SACC, Johannesburg. 